\title{
化学的に熱安定化したビニル系ポリマーからの炭素の調製
}

\author{
山下順也**, 塩谷正俊**
}

(平成14年8月26日受理, 平成14年9月2日採択)

\section{Preparation of Carbon Materials from Chemically Stabilized Vinyl-type Polymers}

\author{
Junya Yamashita** and Masatoshi Shioya**
}

\begin{abstract}
Vinyl-type polymers are attractive as precursor for carbon materials because of their high carbon content and good processability. If these polymers are exposed to a carbonization atmosphere, however a large mass loss and fusion usually take place. Thus, some additional treatment for enhancing the thermal stability of the polymers is required prior to carbonization, and this treatment is referred to as stabilization. Since most of vinyl-type polymers are thermally decomposed only at temperatures above their melting points, it is difficult to stabilize them with a low-temperature heat-treatment in air. It is known that the treatments with chemical agents can convert vinyl-type polymers to the thermal resistant polymers. The present authors have developed the novel production processes of carbon materials from various vinyl-type polymers by using a combination of chemical treatment and high-temperature heat-treatment. This paper reviews the structure and properties of viny-type polymer-based carbon materials.
\end{abstract}

KEYWORDS :Activated carbon, Carbon aerogel, Stabilization, Adsorption properties, Electrochemical properties

\section{1.はじめに}

炭素材料の物性は, 炭素原子の結合様式, 結晶構造, 組織の 配列様式などと同時に, その形態にも大きく依存する。炭素 は, 非常に高温・高圧下でなければ溶融せず, 適当な溶媒も存 在しないため, 所望の形態を有する炭素材料を製造するため には, 通常有機物を所定の形態に成形した後,これを高温で炭 素化する必要がある。有機物の中でも特に合成高分子につい ては, 多様な成形方法か確立されており, 微視的レベルから巨 視的レベルにわたる形態の制御が可能となっている。これら の高分子を炭素に転換できれば, さまざまな形態の炭素材料 を得ることができるはずである。しかし，高温の熱処理過程 において形態を維持して炭素化が進行する高分子は, 元来耐 熱性の高い化学構造を有しているか, あるいは炭素化に先立 って行われる熱安定化と呼ばれる処理によって耐熱性が向上 するものに限られる。一般に熱安定化は前酸化とも呼ばれる ように, 比較的低温の空気中における熱処理によって高分子 を酸化し, 化学構造を熱的に安定なかたちに変化させるもの である。しかし, 軟化点よりも低い温度において,このような
熱変性が起こらない高分子については, 別の何らかの手法に よって熱安定化を行わなければならない。

一般に耐熱性の高い高分子は共役系や芳香族的な環状構造 を含んでおり，炭素含有率が高い。試薬を用いた化学的な手 法によって, 出発高分子をこのような化学構造に転換する試 みに関しては,これまでに多くの研究がなされており，優れた 総説も出版されている1)-3)。その中の多くはビニル系ポリマ 一に関するものであり, Table 1に示すような例が報告されて (いる)-23)。しかしながら,これらの多くは低温で炭素質の物 質を得ることや一次元鎖状炭素であるカルビンを調製するこ とを目的としたものが多く, 高分子から炭素材料を製造する 過程に扔ける熱安定化を目的としたものは少ない。

著者らは,これまでに試薬を用いた液相に扔ける処理や高 反応性ガス中における熱処理による熱安定化を用いて種々の ビニル系ポリマーから炭素材料を調製し, 吸着材料や電池材 料などへの応用を検討してきた24-29)。本論文では著者らの研 究成果を中心に, 化学的な熱安定化と高温熱処理を組み合わ せた炭素材料の調製方法の特徵や, 得られる炭素材料の構造 と物性について概説する。

\footnotetext{
* Corresponding author, E-mail: junya-yamashita@aist.go.jp

* 産業技術総合研究所エネルギー利用研究部門エネルギー貯蔵材料グループ：テ305-8569 茨城県つくば市小野川16-1

* Energy Storage Material Research Group, Institute for Energy Utilization, National Institute of Advanced Industrial Science and

Technology : 16-1 Onogawa, Tsukuba, Ibaraki 305-8569, Japan

** 東京工業大学有機材料工学科：=152-8552 東京都目黒区大岡山2-12-1

** Organic and Polymeric Materials, Tokyo Institute of Technology :2-12-1 O-okayama, Meguro, Tokyo 152-8552, Japan
} 
Table 1 Reactions of vinyl-type polymers with chemical agents.

\begin{tabular}{|c|c|c|c|c|}
\hline Polymer & Chemical structure & Reaction & Chemical agents & References \\
\hline PVC & & Dehydrochlorination & $\begin{array}{l}\text { Sodium amide } \\
\text { Pyridine } \\
\text { Sodium hydroxide } \\
1,8 \text {-diazabicyclo }[5.4 .0] \text { undec-7ene }\end{array}$ & $\begin{array}{l}\text { 4) } \\
\text { 5),6) } \\
\text { 7) } \\
8), 9)\end{array}$ \\
\hline PVDC & & Dehydrochlorination & $\begin{array}{l}\text { Potassium amide } \\
\text { Potassium hydroxide } \\
\text { Potassium t-butoxide }\end{array}$ & $\begin{array}{l}\text { 10) } \\
\text { 11), 12), 13) } \\
\text { 12) }\end{array}$ \\
\hline PVDF & & Dehydrofluorination & $\begin{array}{l}\text { Sodium hydroxide } \\
\text { Potassium t-butoxide } \\
\text { Lithium 2,2,6,6-tetramethylpiperidide } \\
\text { Tetramethylammonium hydroxide } \\
\text { t-Buthylalcohol (electrochemical) }\end{array}$ & $\begin{array}{l}\text { 14), 15) } \\
\text { 15), 16), 17) } \\
\text { 15) } \\
15) \\
18)\end{array}$ \\
\hline PVA & $\mathrm{OH} \int_{\mathrm{n}}$ & Dehydration & $\begin{array}{l}\text { Hydrogen chloride gas } \\
\text { Acid } \\
\text { Sodium acetate } \\
\text { Sodium hydrogen sulfate } \\
\text { Bromine vapor }\end{array}$ & $\begin{array}{l}\text { 19), 20) } \\
\text { 21) } \\
21) \\
22) \\
23)\end{array}$ \\
\hline
\end{tabular}

\section{2. ポリフッ化ビニリデン系炭素䋳維およびフィルム}

ポリフッ化ビニリデン (PVDF) は $175^{\circ} \mathrm{C}$ 付近に融点をもつ 結晶性の熱可塑性高分子である。フッ化水素ガスの放出を 伴う熱分解反応は, 融点よりも非常に高い $350^{\circ} \mathrm{C}$ 以上になら ないと起こらないため, 熱処理によってPVDFを熱安定化す ることは困難である。Pendletoneらは, PVDFと同じハロゲ ンを含むビニル系ポリマーであるポリ塩化ビニリデンを強 塩基によって化学的に脱塩化水素化した後, 高温で熱処理す ることによって, 直径 $0.1 \mu \mathrm{m}$ の炭素粒子を調製することに成功 している12)。そこで, PVDF纎維およびフィルムに対して強塩 基による脱フッ化水素化と高温熱処理を施すことによって, 炭素繊維およびフィルムを調製することを試みた。

直径7〜10 $\mu \mathrm{m}$ のPVDF繊維は複合溶融紡系法により, 厚さ $120 \mu \mathrm{m}$ のPVDFフィムはホットプレス法により, それぞれ 得た。PVDFの脱フッ化水素化は有機系の強塩基の1つであ る, 1,8-ジアザビシクロ [5,4,0] -7-ウンデセン (DBU) を用い て行った。試料形態を保って, 脱フッ化水素化を試料内部ま で速やかに進行させるためには, 試料を溶媒によって適度に 膨潤させる必要がある。そこでDBUを溶解させる溶媒とし て, PVDFの良溶媒であるジメチルホルムアミド (DMF) と貧 溶媒であるエ夕ノール (EtOH) の混合溶媒 (体積比DMF/ $\mathrm{EtOH}=2 / 3$ ）を用いた。PVDF分子中のフッ素原子に対する DBU分子のモル比が, 2 に相当する量の1.0MDBU溶液に, PVDF繊維あるいはフィルムを $70^{\circ} \mathrm{C} て ゙$ 種々の時間浸漬して脱 フッ化水素化を行った。

脱フッ化水素化によって, PVDFの色は白色から黒色へ変化 した。試料内部への脱フッ化水素化の進行は速やかであり，

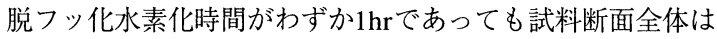
一様に黒色に変化していた。Fig.1に示すように, 脱フッ化水 素化による質量減少率 $\left(\Delta M_{\text {chem }} / M_{P V D F}\right)$ は, 処理時間の増加に

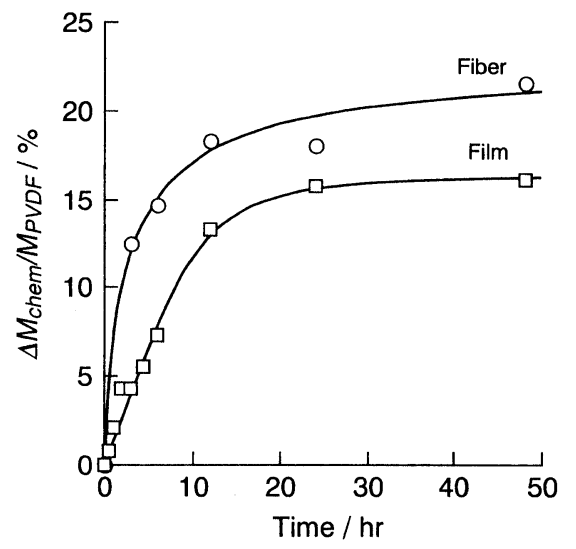

Fig.1 Relative mass loss during dehydrofluorination $\left(\Delta M_{\text {chem }}\right.$ ) $\left.M_{P V D F}\right)$ of PVDF fibers and films versus dehydrofluorination time ${ }^{24)}$.

伴って増大した。Fig.2に示すように, 脱フッ化水素化物中の フッ素原子の質量分率は $\Delta M_{\text {chem }} / M_{P V D F}$ の増加に対して, ほぼ直 線的に減少するのに対して, 炭素の質量分率は増大した。脱 フッ化水素化物中の元素組成と $\Delta M_{\text {chem }} / M_{P V D F}$ の関係は, 試料形 態に依存しないことから, $\Delta M_{\text {chem }} / M_{P V D F}$ を脱フッ化水素化の程 度を表す指標として適用した。Fig.3に種々の程度まで脱フ ッ化水素化を行ったPVDF繊維の赤外吸収スペクトル（IRス ペクトル）を示した。PVDF固有の吸収は脱フッ化水素化の 進行に伴って徐々に消失し, かわって $1500 \sim 1800 \mathrm{~cm}^{-1}$ と $2100 \mathrm{~cm}^{-1}$ にブロードな吸収バンドと弱い吸収バンドがそれ ぞれ現れた。これらはC-C二重結合およびC-C三重結合の伸 縮振動にそれぞれ帰属される ${ }^{14)}$ 。C-C二重結合に帰属される 吸収バンドがブロードであるのは, 種類の異なるいくつかの 二重結合が存在していることを示唆している14)。C-C三重結 合はフッ化ビニリデンモノマーから2つのフッ化水素分子が 脱離することによって形成される14)。Fig.4に種々の程度まで 

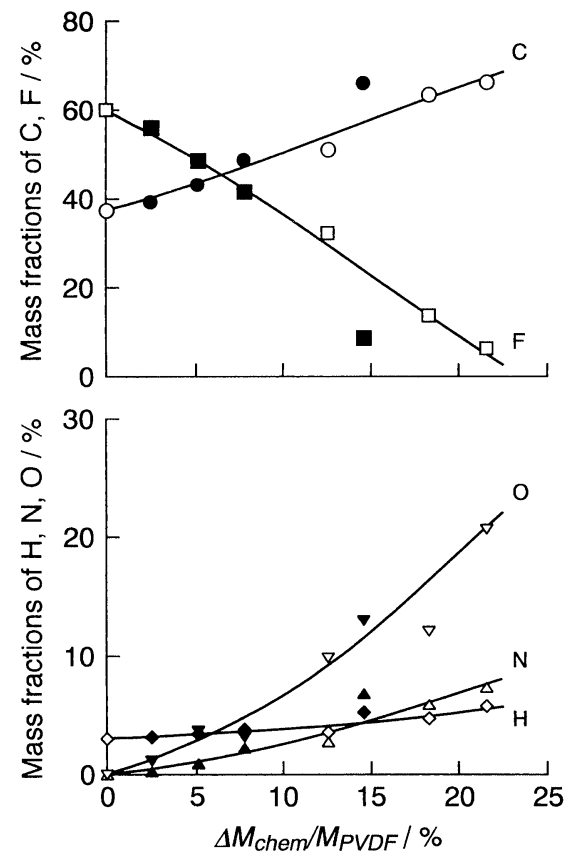

Fig.2 Mass fractions of hydrogen, carbon, nitrogen, oxygen and fluorine in dehydrofluorinated PVDF fibers (open symbol) and films (closed symbol) versus $\Delta M_{\text {chem }} / M_{P V D F}{ }^{24)}$.

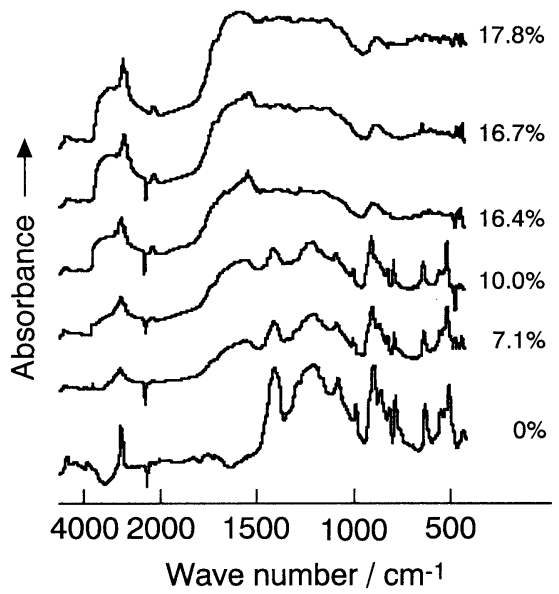

Fig.3 IR spectra of dehydrofluorinated PVDF fibers. Values of $\Delta M_{\text {chem }} / M_{P V D F}$ are shown in the figure ${ }^{25)}$.

脱フッ化水素化を行ったPVDFフィルムのDSC曲線を示した。 PVDF結晶の融解に起因する吸熱ピークは, 脱フッ化水素化の 進行に伴って徐々に減少し, 最終的に消失した。Fig.5に示す ように, 出発のPVDF㵶維およびフィルムのSAXSプロフィー ルには, 周期的に配列したPVDFの結晶領域と非晶領域からな る長周期構造に由来する散乱ピークが生じる。PVDF瀻維の 長周期は約 $12 \mathrm{~nm}$ であり, 瀻維軸に対して平行に配列してい る。 $\Delta M_{\text {chem }} / M_{P V D F}$ が約 $8 \%$ までは脱フッ化水素化によって SAXS ピークは強まるが,それ以上に処理の程度が高まるとピ 一クは弱まり,最終的に消失した。PVDFの非晶領域は結晶領

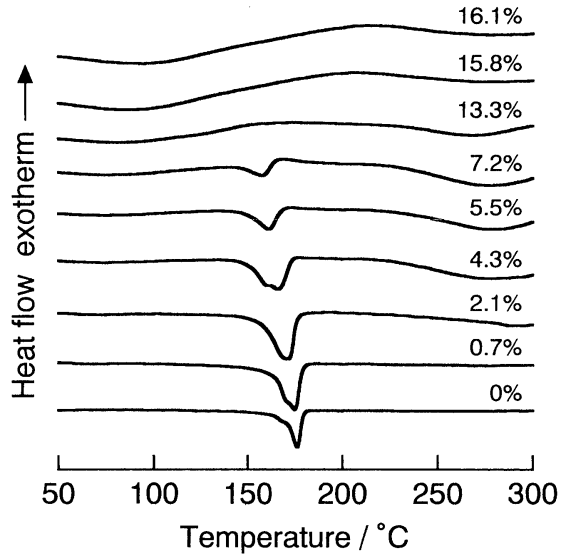

Fig.4 DSC diagrams of dehydrofluorinated PVDF films. Values of $\Delta M_{\text {chem }} / M_{P V D F}$ are shown in the figure ${ }^{25)}$.
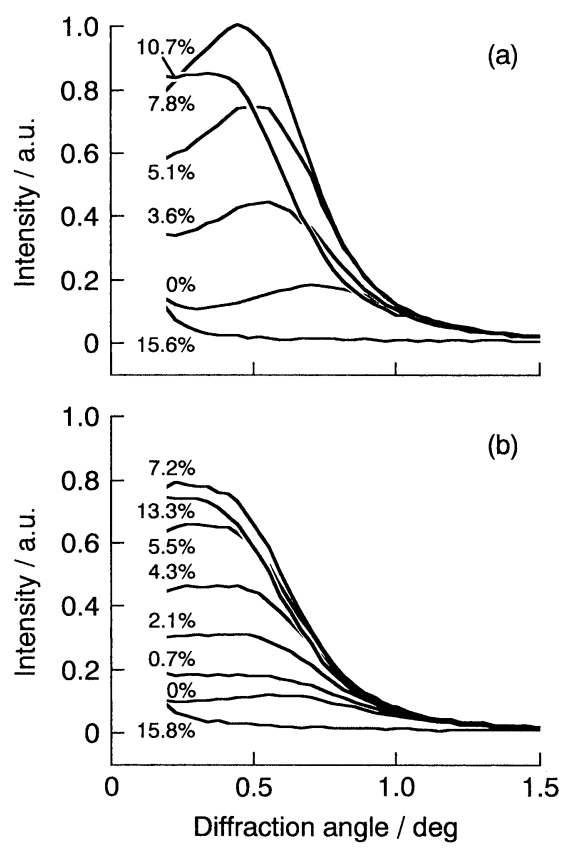

Fig.5 (a) Meridional SAXS profiles of dehydrofluorinated PVDF fibers and (b) SAXS profiles measured by impinging the X-ray beam on the surface of dehydrofluorinated PVDF films. Values of $\Delta M_{\text {chem }} / M_{P V D F}$ are shown in the figure $^{25)}$.

域に比べてDMFによって膨潤しやすいため, 脱フッ化水素化 はPVDFの非晶領域において優先的あるいは速い速度で進行 し, 最終的に結晶領域において完了すると考えられる。この 考えに基づくと, IRスペタトル, DSCおよびSAXSの結果を以 下のように矛盾なく説明できる。処理の初期段階に扔いて非 晶領域が選択的に脱フッ化水素化されることによって非晶領 域の密度が減少し, 結晶領域と非晶領域の電子密度差が増大 する。その結果, SAXSピークは強まる。2つの領域において 脱フッ化水素化が進行することによって, 電子密度差が再び小 
さくなりSAXSピークは弱まる。脱フッ化水素化によって結 晶領域が完全に消失すると, 長周期構造に起因するSAXSピー ク,PVDF結晶の融解によるDSC吸熱ピークおよびPVDFセグ メントによるIR吸収バンドが消失する。これらが消失するの はいずれも $\Delta M_{\text {chem }} / M_{P V D F}$ が拉よそ $15 \%$ となるまで脱フッ化水 素化を行ったときであった。

脱フッ化水素化によってPVDFは高温においても不融性と

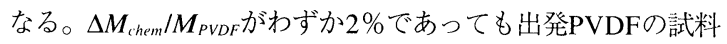
形態を保持して炭素化することが可能であった。その結果, 脱フッ化水素化物からは, しわや変形などの欠陥のない炭素 瀻維㧍よびフィルムが得られた。一方, 脱フッ化水素化を施 さないとPVDFは熱処理過程中において溶融し, 粒状の炭素が 得られるにすぎなかった。Fig.6に示すように, 脱フッ化水素 化物は300 $400^{\circ} \mathrm{C} の$ 温度域において急激な分解を起こし質量 が減少する。この温度域においてPVDF系炭素にはSAXSに よって検出できる程度のサイズの細孔が形成される。Fig.7 にSAXSプロフィールから求めたPVDF系炭素の細孔の慣性 半径 $\left(R_{3}\right)$ を $\Delta M_{\text {chem }} / M_{P V D F}$ に対してプロットした。 $R_{3}$ は著者ら が考案した方法に従って求めた30)。同程度の熱処理温度で炭 素化して得たピッチ系, ポリアクリロニトリル(PAN) 系拉よ びフェノール系炭素繊維のR 3 は, それぞれ $1.2,0.8$ および $0.9 \mathrm{~nm}$ であった。市販されている粒状活性炭については $2.1 \mathrm{~nm}$ った。PVDF系炭素のR 3 は, $\Delta M_{\text {chem }} / M_{P V D F}$ が $2 \%$ 程度のわずか な脱フッ化水素化によって増大した。脱フッ化水素化の程度 をさらに高めるとR 3 は $2.3 \mathrm{~nm}$ から $0.3 \mathrm{~nm}$ まで減少した。した がって,PVDF系炭素の細孔サイズは脱フッ化水素化の程度を 変化させることによって広範囲にわたって制御できることが わかる。程度の低い脱フッ化水素化によって形成されるサイ ズの大きな細孔の形成機構は以下のように考えられる： $\Delta M_{\text {chem }} / M_{P V D F}$ が15\%以下の脱フッ化水素化物には, 脱フッ化水 素化された非晶領域と末反応の結晶領域が含まれている。未 反応の結晶領域は融点に扔いて融解し, 溶融状態において分 解が起こる。脱フッ化水素化物は熱処理過程において, その 形態を保持できることから, 脱フッ化水素化された領域は分 解過程において溶融・流動することはなく, 未反応領域が融 点以上で流動することを防ぐ“骨組み”として働いていると 考えられる。Fig.6からわかるように, 分解過程における未反 応領域の質量減少, 寸なわち体積減少は, 脱フッ化水素化され た骨組み部分のそれとは異なる。したがって, サイズの大き な細孔は熱処理過程における体積収縮の違いによって, 骨組 み部分とそれに内包された部分との間に形成されると考えら れる。一方, 脱フッ化水素化の程度が高まるとPVDFは均一に 脱フッ化水素化されるため,このような大きな細孔は形成さ れない。

一般に炭素繊維は軸方向の引張強度に比べて圧縮強度が著 しく小さく,このことが圧縮加重が負荷される構造部材への 炭素瀻維強化複合材料の利用を制限している。例えば, 引張

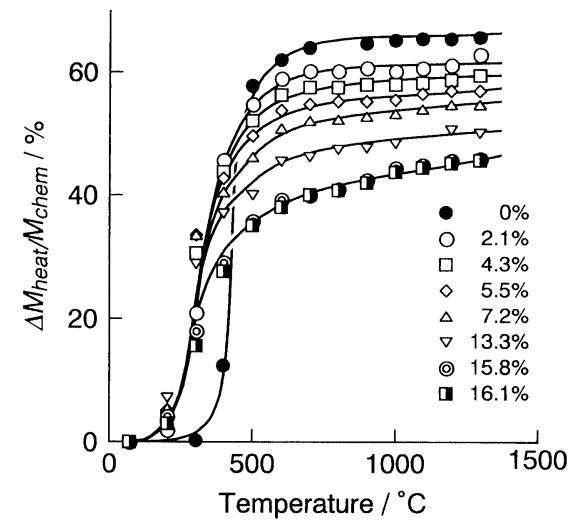

Fig.6 Relative mass loss during heat-treatment $\left(\Delta M_{\text {heut }} / M_{\text {chem }}\right)$ of dehydrofluorinated PVDF films versus heat-treatment temperature. Values of $\Delta M_{\text {chem }} / M_{P V D F}$ are shown in the figure ${ }^{25)}$.

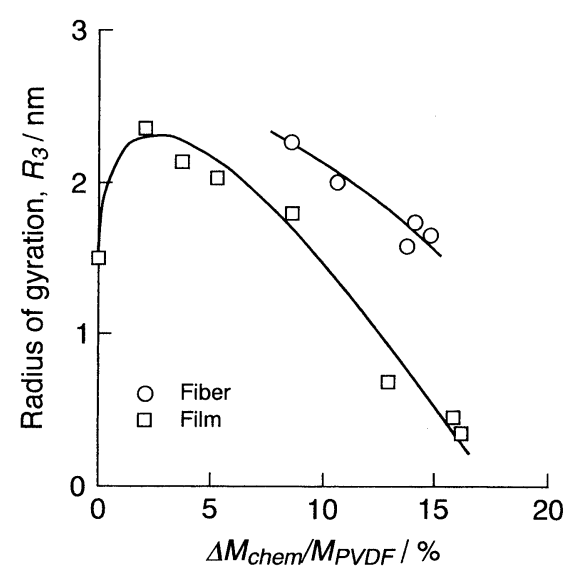

Fig.7 Radius of gyration $\left(R_{3}\right)$ of pores in PVDF-based carbon fibers and films versus $\Delta M_{\text {chem }} / M_{P V D F}$. Heat-treatment temperature was $1300^{\circ} \mathrm{C}$. At $\Delta M_{\text {chem }} / M_{P V D F}=0$, film was pulverized during heat-treatment ${ }^{25)}$.

強度が5.7GPaを超える高性能PAN系炭素纎維の圧縮強度は $2.2 \mathrm{GPa}$ 程度である ${ }^{31}$ 。著者らは, これまでに炭素瀻維の圧縮 破壊機構を結晶構造や細孔構造に基づいて検討し,さまざま な炭素瀻維の圧縮強度を定量的に表すことができる破壊モデ ルを提案した ${ }^{32}$ 。この破壞モデルは, 細孔近傍に存在する炭 素結晶中の炭素網面が個々に座屈を起こすことによって繊維 が圧縮破壞に至るとするものである。この破壊モデルによる と, 炭素䋐維の圧縮強度は細孔の繊維軸に対して垂直な断面 の面積に反比例する。したがって, 圧縮強度を高めるために は細孔のサイズを小さくすることが有効である。PVDF系炭 素繊維は, 程度の高い脱フッ化水素化を行うことによって, 細 孔サイズを通常の炭素瀻維よりも小さくすることができる。 $\Delta M_{\text {chem }} / M_{P V D F}$ が16\%となる脱フッ化水素化を行って得たPVDF 系炭素繊維の引張強度および圧縮強度はそれぞれ0.68および $1.31 \mathrm{GPa}$ であり,引張強度に対する圧縮強度の比は通常の炭素 


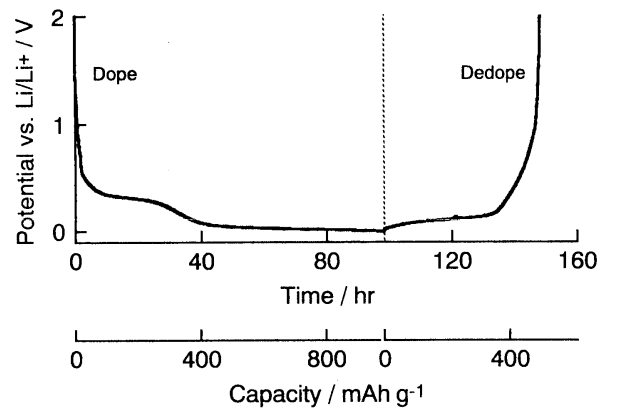

Fig.8 Charge-discharge curve at first cycle of PVDF-based carbon film prepared with the condition of $\Delta M_{\text {chem }} / M_{P V D F}=2.1 \%$ and Carbonization temperature $=$ $900^{\circ} \mathrm{C}$. Current density was $10 \mathrm{mAg}^{-1}$.

繊維に比べて著しく高い值となった。

比較的低温で熱処理して得られる難黒鉛化性炭素は, 黒鉛 への電気化学的なリチウムイオンのインターカレーションに よる理論吸蔵容量である $372 \mathrm{mAhg}^{-1}$ を超える高い吸蔵・脱離 容量を示すことが知られており, 高容量リチウムイオン二次 電池の負極材料として期待されている331-38〉。そこで, 種々の 条件で作製したPVDF系炭素フィルムについて, そのリチウム イオン二次電池負極特性を評価した。Fig.8にPVDF系炭素フ イルムの代表的なリチウムイオンドープ・脱ドープ曲線を示 した。通常の難黒鉛化性炭素ではリチウムイオンは $0 \mathrm{~V}$ 付近 でドープされ $1 \mathrm{~V}$ 付近で脱ドープされる34)-38)。それに対して, PVDF系炭素フィルムではOV付近でドープされたリチウムイ オンのほとんどが同じ0V付近で脱ドープされることがわか る。これは実際の電池として有用な $4 \mathrm{~V}$ 程度の高い起電力に おける容量が大きいことに相当することから, PVDF系炭素は 負極材料として優れた特性を有していると言える。

脱フッ化水素化および高温熱処理を用いて得られるPVDF 系炭素の細孔は閉気孔であり,これらを吸着に寄与する開気 孔にするには,さらに賦活を施す必要がある。そこで, PVDF 系炭素を高温の二酸化炭素ガス気流中において賦活し, 得ら れた活性炭の吸着特性を明らかにした。Fig.9に種々の脱フ ッ化水素化条件で得られたPVDF系活性炭素フィルムの窒素 ガス吸脱着等温線を比較した。賦活による質量減少率は,いず れの試料についても70\%程度である。程度の低い脱フッ化水 素化を行って得られた活性炭素フィルムの等温線は, メソ孔の 存在を示唆するヒステリシスループを示す39)。Fig.10にPVDF 系活性炭のメチレンブルー $(\mathrm{MB})$ 吸着量を $\Delta M_{\text {chem }} / M_{P V D F}$ に対 してプロットした。MB分子は $1.5 \mathrm{~nm}$ よりも大きな細孔に進 入し吸着する40)。Fig.7 とFig.10を比較すると, 活性炭のMB吸 着量は賦活前の炭素の細孔構造に強く依存していることがわ かる。程度の低い脱フッ化水素化を行って得られた活性炭素 フィルムは, ほかの活性炭と比較して極めて高いMB吸着量 $510 \mathrm{mgg}^{-1}$ を示した ${ }^{41)}$ 。PVDF系活性炭の利点は金属粒子など の不純物をいっさい含んでいないことである。これは活性炭

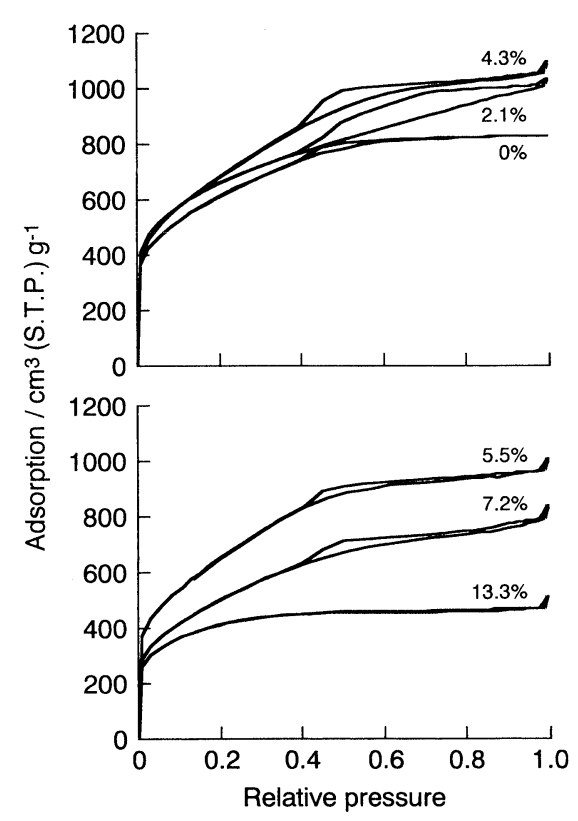

Fig.9 Nitrogen gas adsorption desorption isotherms at $-196^{\circ} \mathrm{C}$ for PVDF-based activated carbon films and granule. Values of $\Delta M_{\text {chem }} / M_{P V D F}$ are shown in the figure and burnoff at activation was about $70 \%$ for all specimens.

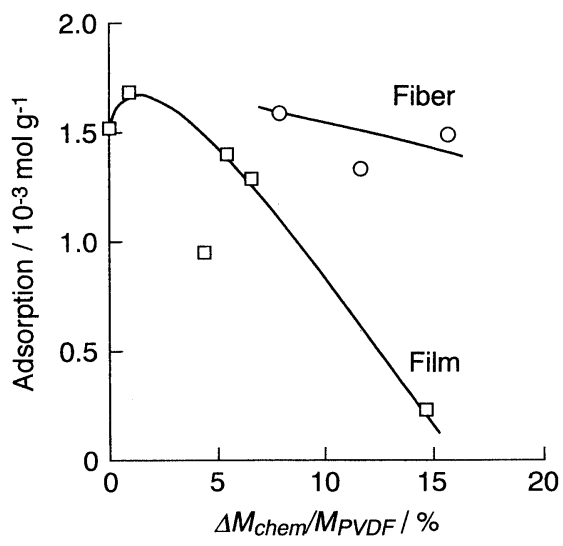

Fig.10 Methylene blue adsorption capacity versus $\Delta M_{\text {chem }} / M_{P V D F}$ for PVDF-based activated carbon films and granule. Burn-off at activation was about $70 \%$ for all specimens $^{26)}$.

を触媒担体や電気二重層キャパシタの電極に応用する上で好 ましい。細孔サイズは脱フッ化水素化の程度を変化させるこ とによって制御できる。また, 繊維やフィルムなどの材料とし て有用な形態のものが得られることも有利な点である。

\section{3. ポリ塩化ビニル系カーボンエアロゲル}

2章では炭素繊維およびフィルムを得るために, PVDF繊維 やフィルムを適度に膨潤させた状態で脱フッ化水素化を行っ た。一方, ハロゲンを含むビニル系ポリマーを良溶媒に溶解 
させ,この溶液に脱ハロゲン化水素化を行うと, 分子鎖間にお ける脱八ロゲン化水素化による架橋形成によってゲルが生成 する。このゲル中の溶媒を超臨界乾燥によって除去すれば, 熱的に安定な有機質のエアロゲルが得られる可能性がある。 さらにこの有機質エアロゲルを高温熱処理すれば, カーボン エアロゲルに転換できる可能性がある。これまでに報告され ているカーボンエアロゲルはレゾルシノールなどの低分子化

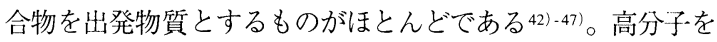
出発物質とするカーボンエアロゲルの細孔構造は低分子を出 発物質とするものとは異なることが予想される。そこで, 出 発物質として有機溶剤への溶解性に優れるポリ塩化ビニル (PVC) を用いて, 有機質エアロゲルおよびカーボンエアロゲ ルを調製することを試みた。

数平均分子量 $\left(M_{n}\right)$ が $22,000,47,000$ および 82,000 の種類 のPVC粉末を出発原料として用いた。PVC粉末をジメチルホ ルムアミド (DMF) に溶解させ, PVC溶液を擋拌しながら脱塩 化水素化剤である1,8-ジアザビシクロ [5,4,0]-7-ウンデセン (DBU) を滴下した。PVC分子中の塩素原子に対するDBU分 子のモル比 $(D B U / C l)$ は, $0.1 \sim 10.0$ 範囲で変化させた。 $\mathrm{PVC} / \mathrm{DMF} / \mathrm{DBU} 3$ 成分からなる溶液中におけるPVCの濃度 ([PVC]) は, 2.5 15.0wt\%の範囲で変化させた。脱塩化水素 化を促進するために, ガラス管に封入した溶液を 30,50 および

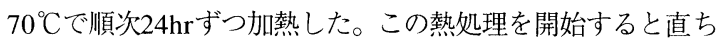
に溶液は無色から黒色へと変化した。熱処理が進行するに従 って, 溶液は粘调になり最終的にゲル化した。ゲルを大きく 収縮させることなく乾燥するために，まずゲル中のDMFを液 体二酸化炭素で置換し, 次に二酸化炭素を超臨界状態に打い てゲルから除去した。

$[P V C]$ および $M_{n}$ が一定のとき, 有機質エアロゲルの細孔容 積はDBU/Clが2.0において最大となった。そこでDBU/Clを
1.0あるいは2.0に固定し, $[P V C]$ および $M_{n}$ をさまざまに変化 させて有機質エアロゲルを作製した。有機質エアロゲルの調 製条件と細孔構造特性をTable 2 にまとめた。細孔構造特性 值は次のようにして求めた：かさ密度 $\left(\rho_{\text {bulk }}\right)$ は, 質量/かさ 体積として求めた。ここでかさ体積は, 試料の巨視的なサイ ズから計算した。見掛け密度 $\left(\rho_{a p p}\right)$ は, 隇圧下における試料の 質量と炭酸プロピレンに浸漬した試料の質量から求めた。全 細孔容積 $\left(V_{\text {den }}\right)$ は, $\left(1 / \rho_{\text {bulk }}\right)-\left(1 / \rho_{\text {app }}\right)$ として求めた。 $V_{a d}$ とし

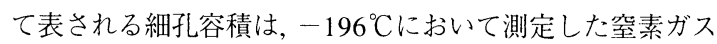
吸脱着等温線の相対圧 0.99 における吸着量と液体窒素の密度 $0.808 \mathrm{gcm}^{-3}$ から求めた。細孔容積の差, $V_{d e n}-V_{a d}$ はマク口孔 容積に相当する。メソ孔のサイズ分布は, 脱着等温線を Dollimore-Heal法に従って解析することによって求めた48)。 分布が最大值をとるメり孔半径を $R_{\text {mess }}$ *として表した。ミク 口孔容積 $\left(V_{\text {mic }}\right)$ は, 相対圧が 0.10 よりも小さい範囲における吸 着等温線を, Dubinin-Radushkevich法に従って解析すること によって求めた49)。BET比表面積 $\left(S_{B E T}\right)$ は, 相対圧 $0.05 \sim 0.30$ の範囲における吸着等温線から求めた。 $[P V C]=2.5 \mathrm{wt} \% の$ 条件を用いて作製した有機質エアロゲル (試料A，B，J掞よび K)については $V_{d e n}$ が $V_{a d} に$ に比べて著しく大きいことから, 相当 量のマクロ孔が含まれていることがわかる。 $D B U / C l$ おび $M_{n}$ が一定の条件下に打いて $[P V C]$ を減少させると, メソ孔の 容積およびサイズを増大させることができる (ex.試料B，Eお よびH)。DBU/Clおよび $[P V C]$ が一定の条件下において $M_{n}$ を滅少させると,メソ孔のサイズを大きく変化させることな くメソ孔の容積を増大させることができる (ex.試料F, G拉よ びH）。Fig.11に示すように有機質エアロゲルは調製条件によ らず単分散で狭いメソ孔サイズ分布をもっている。 $D B U / C l$, $[P V C]$ および $M_{n}$ を変化させることによって, $R_{\text {meso }}$ *は2.9 $20.0 \mathrm{~nm}$ の範囲で制御することが可能である。有機質エアロゲ

Table 2 Preparation conditions and characteristics of pores in organic aerogels ${ }^{27}$.

\begin{tabular}{ccccccccccc}
\hline Specimens & $D B U / C l$ & $\begin{array}{r}{[P V C]} \\
(\mathrm{wt} \%)\end{array}$ & $\begin{array}{l}M_{n} \\
\left(/ 10^{4}\right)\end{array}$ & $\begin{array}{l}\rho_{\text {bulk }} \\
\left(\mathrm{g} / \mathrm{cm}^{3}\right)\end{array}$ & $\begin{array}{l}\rho_{\text {app }} \\
\left.\left(\mathrm{g}_{\mathrm{cm}}\right)^{3}\right)\end{array}$ & $\begin{array}{l}V_{\text {den }} \\
\left(\mathrm{cm}^{3} / \mathrm{g}\right)\end{array}$ & $\begin{array}{l}V_{\text {ad }} \\
\left(\mathrm{cm}^{3} / \mathrm{g}\right)\end{array}$ & $\begin{array}{l}V_{\text {micro }} \\
\left(\mathrm{cm}^{3} / \mathrm{g}\right)\end{array}$ & $\begin{array}{l}S_{B E T} \\
\left(\mathrm{~m}^{2} / \mathrm{g}\right)\end{array}$ & $\begin{array}{l}R_{\text {meso }} * \\
(\mathrm{~nm})\end{array}$ \\
\hline $\mathrm{A}$ & 1.0 & 2.5 & 4.7 & 0.21 & 1.24 & 3.95 & 1.64 & 0.13 & 345 & 15.3 \\
$\mathrm{~B}$ & 1.0 & 2.5 & 8.2 & 0.25 & 1.22 & 3.15 & 1.46 & 0.14 & 389 & 20.0 \\
$\mathrm{C}$ & 1.0 & 5.0 & 2.2 & 0.28 & 1.21 & 2.64 & 2.08 & 0.16 & 436 & 20.0 \\
$\mathrm{D}$ & 1.0 & 5.0 & 4.7 & 0.42 & 1.18 & 1.51 & 1.41 & 0.16 & 418 & 8.1 \\
$\mathrm{E}$ & 1.0 & 5.0 & 8.2 & 0.45 & 1.18 & 1.36 & 1.06 & 0.14 & 364 & 6.1 \\
$\mathrm{~F}$ & 1.0 & 10.0 & 2.2 & 0.44 & 1.18 & 1.39 & 1.18 & 0.17 & 443 & 6.1 \\
$\mathrm{G}$ & 1.0 & 10.0 & 4.7 & 0.51 & 1.17 & 1.10 & 0.89 & 0.19 & 392 & 4.2 \\
$\mathrm{H}$ & 1.0 & 10.0 & 8.2 & 0.52 & 1.17 & 1.06 & 0.93 & 0.15 & 393 & 4.5 \\
$\mathrm{I}$ & 1.0 & 15.0 & 2.2 & 0.50 & 1.17 & 1.12 & 0.99 & 0.21 & 465 & 2.9 \\
$\mathrm{~J}$ & 2.0 & 2.5 & 2.2 & 0.08 & 1.40 & 10.52 & 0.99 & 0.15 & 404 & 20.0 \\
$\mathrm{~K}$ & 2.0 & 2.5 & 4.7 & 0.19 & 1.25 & 4.38 & 0.88 & 0.13 & 358 & 11.7 \\
$\mathrm{~L}$ & 2.0 & 2.5 & 8.2 & 0.21 & 1.24 & 3.82 & 2.80 & 0.17 & 447 & 20.0 \\
$\mathrm{M}$ & 2.0 & 5.0 & 2.2 & 0.26 & 1.22 & 2.96 & 2.10 & 0.18 & 478 & 11.7 \\
$\mathrm{~N}$ & 2.0 & 5.0 & 4.7 & 0.34 & 1.19 & 2.07 & 1.75 & 0.17 & 432 & 9.6 \\
$\mathrm{O}$ & 2.0 & 5.0 & 8.2 & 0.34 & 1.19 & 2.05 & 1.71 & 0.17 & 459 & 9.6 \\
$\mathrm{P}$ & 2.0 & 10.0 & 2.2 & 0.43 & 1.18 & 1.46 & 1.47 & 0.21 & 571 & 5.5 \\
$\mathrm{Q}$ & 2.0 & 10.0 & 4.7 & 0.44 & 1.18 & 1.38 & 1.34 & 0.23 & 621 & 4.2 \\
\hline
\end{tabular}


ルのミクロ孔容積は小さく,またその調製条件に対する依存 性も小さい。

PVCを脱塩化水素化して得られる有機質エアロゲルは, PVDFの脱フッ化水素化物とは異なり, 高温の熱処理過程にお いて溶融し, 大きな質量減少を示した。そこで, 有機質エアロ

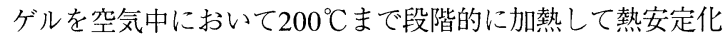
した後, 炭素化してカーボンエアロゲルを調製した。得られ たカーボンエアロゲルの細孔構造特性をTable 3 に示した。 $[P V C]=10.0$ および $15.0 \mathrm{wt} \%$ の条件を用いて作製した有機質 エアロゲル (試料F, G, H, I, PおよびQ)については, 試料内部 が十分熱安定化されず, 炭素化過程において溶融した。熱安 定化および炭素化過程においてエアロゲルのネットワーク構 造は, 分解ガスの放出による質量減少と物質の高密度化によ って収縮する。ネットワーク構造の収縮に伴って, エアロゲ ル中のマクロ孔およびメソ孔も収縮する。試料Jを除くほか のカーボンエアロゲルについては $V_{d e n}$ が $V_{a d}$ とほぼ等しいこと から，これらのカーボンエアロゲル中にはマクロ孔がほとん ど含まれていないことがわかる。カーボンエアロゲルのメソ 孔サイズ分布をFig.12に示した。Fig.11およびFig.12を比較 すると, 熱安定化および炭素化によって, 分布はより小さいサ イズにシフトすることがわかる。また, 分布曲線の積分值で 与えられるメソ孔容積も減少する。 $\mathrm{DBU} / \mathrm{Cl},[\mathrm{PVC}]$ および $M_{\mathrm{n}}$ を変化させることによって, カーボンエアロゲルの $R_{\text {meso }} *$ * 4.5 15.3nmの範囲で制御することが可能である。制御可能 な細孔径範囲は, レゾルシノール系エアロゲルに比べてPVC 系エアロゲルのほうが大きい46)。レゾルシノール系エアロゲ ルの製造過程においては, 湿潤ゲル中の水を液体二酸化炭素 に対する溶解度が高いアセトンによって置換した後,このア セトンを液体二酸化炭素によって置換する二段階の溶媒置換 が必要となる46)。それに対してPVC系エアロゲルの製造過程 においては, 湿潤ゲル中のDMFを液体二酸化炭素によって直 接置換することができるため, 製造工程を短縮することがで きる。
熱安定化の雲囲気は有機物の炭素化挙動や最終的に得られ る炭素の構造に大きな影響を及(゙す(9).20150)-53)。ピッチを炭素

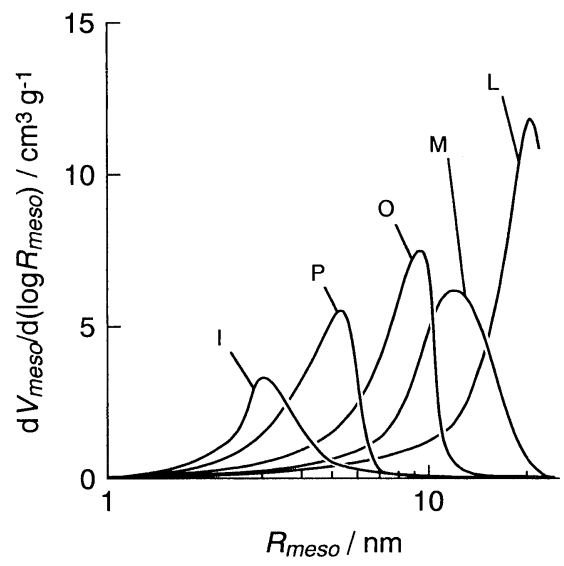

Fig.11 Distributions of mesopore radius $\left(\boldsymbol{R}_{\text {meso }}\right)$ for organic aerogels shown in Table $\mathbf{2}^{27)}$.

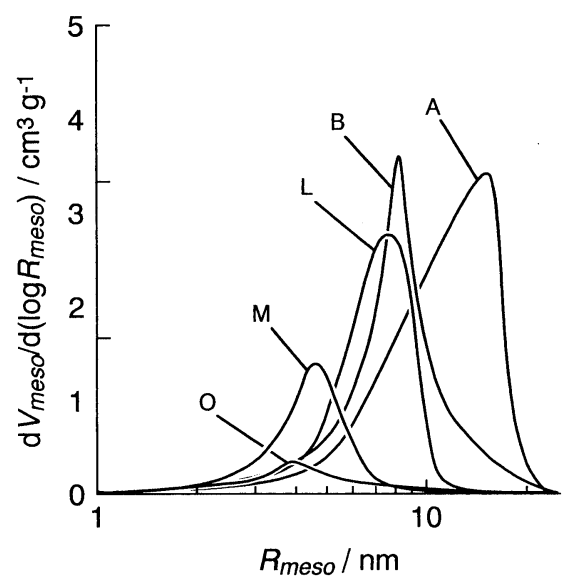

Fig.12 Distributions of mesopore radius $\left(\boldsymbol{R}_{\text {meso }}\right)$ for carbon aerogels derived from organic aerogels shown in Table 2. Maximum stabilization temperature was $200^{\circ} \mathrm{C}$. Carbonization temperature was $1000^{\circ} \mathrm{C}^{27)}$.

Table 3 Preparation conditions and characteristics of pores in carbon aerogels ${ }^{27)}$.

\begin{tabular}{ccccccccccc}
\hline Specimens & $D B U / C l$ & $\begin{array}{c}{[P V C]} \\
(\mathrm{wt} \%)\end{array}$ & $\begin{array}{l}M_{n} \\
\left(/ 10^{4}\right)\end{array}$ & $\begin{array}{l}\rho_{\text {bulk }} \\
\left(\mathrm{g}_{\mathrm{cm}}^{3}\right)\end{array}$ & $\begin{array}{l}\rho_{\text {app }} \\
\left(\mathrm{g} / \mathrm{cm}^{3}\right)\end{array}$ & $\begin{array}{l}V_{\text {den }} \\
\left(\mathrm{cm}^{3} / \mathrm{g}\right)\end{array}$ & $\begin{array}{l}V_{\text {ad }} \\
\left(\mathrm{cm}^{3} / \mathrm{g}\right)\end{array}$ & $\begin{array}{l}V_{\text {micro }} \\
\left(\mathrm{cm}^{3} / \mathrm{g}\right)\end{array}$ & $\begin{array}{l}S_{B E T} \\
\left(\mathrm{~m}^{2} / \mathrm{g}\right)\end{array}$ & $\begin{array}{l}R_{\text {meso }} * \\
(\mathrm{~nm})\end{array}$ \\
\hline $\mathrm{A}$ & 1.0 & 2.5 & 4.7 & 0.57 & 1.70 & 1.14 & 1.28 & 0.16 & 340 & 15.3 \\
$\mathrm{~B}$ & 1.0 & 2.5 & 8.2 & 0.69 & 1.63 & 0.82 & 0.82 & 0.14 & 312 & 8.1 \\
$\mathrm{C}$ & 1.0 & 5.0 & 2.2 & 0.89 & 1.64 & 0.50 & 0.54 & 0.15 & 317 & 4.5 \\
$\mathrm{D}^{\mathrm{a}}$ & 1.0 & 5.0 & 4.7 & 1.14 & 1.21 & 0.04 & & & & \\
$\mathrm{E}^{\mathrm{a}}$ & 1.0 & 5.0 & 8.2 & 1.16 & 1.23 & 0.05 & & & & \\
$\mathrm{~J}$ & 2.0 & 2.5 & 2.2 & 0.31 & 1.65 & 2.55 & 0.75 & 0.14 & 323 & 20.0 \\
$\mathrm{~K}$ & 2.0 & 2.5 & 4.7 & 0.69 & 1.65 & 0.84 & 0.85 & 0.13 & 267 & 15.3 \\
$\mathrm{~L}$ & 2.0 & 2.5 & 8.2 & 0.74 & 1.65 & 0.74 & 0.74 & 0.12 & 273 & 8.1 \\
$\mathrm{M}$ & 2.0 & 5.0 & 2.2 & 0.98 & 1.63 & 0.40 & 0.39 & 0.10 & 221 & 4.5 \\
$\mathrm{~N}$ & 2.0 & 5.0 & 4.7 & 1.29 & 1.44 & 0.07 & & & & \\
$\mathrm{O}$ & 2.0 & 5.0 & 8.2 & 1.18 & 1.49 & 0.17 & 0.16 & 0.03 & 79 & 3.8 \\
\hline
\end{tabular}

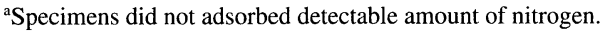


に転換する場合に, 熱安定化の雲囲気としてヨウ素蒸父を用い ると炭素の収率が著しく向上することが知られている501-531。 そこで, PVC系有機質エアロゲルをヨウ素蒸気中において熱 安定化し, 空気中において熱安定化したエアロゲルとの炭素 化挙動の違いを検討した。

ヨウ素蒸気による熱安定化は, 有機質エアロゲルを $100^{\circ} \mathrm{Cに}$ おけるヨウ素の飽和蒸気に種々の時間暴露することによって 行った。ヨウ素の試料内部への拡散は非常に速やかであり, 熱安定化反応は断面内に扔いて均一に進行した。その結果, 空気によって熱安定化したエアロゲルとは対照的に, ヨウ素 蒸気によって熱安定化したエアロゲルは出発溶液の組成にか かわらず炭素化過程において溶融することはなかった。

Fig.13に有機質エアロゲル, 空気掞よびヨウ素によって熱安 定化したエアロゲルのIRスペクトルを比較した。有機質エア ロゲルは, $1600 \mathrm{~cm}^{-1}$ 付近にC-C二重結合の伸縮振動に帰属さ れるブロードな吸収バンドを示す8)。また, 有機質エアロゲル は, 1007 おび $3019 \mathrm{~cm}^{-1}$ にそれぞれ連続したC-C二重結合の C-H面外変角振動, および不飽和炭素のC-H伸縮振動に帰属さ れる吸収バンドを示す8)。これら2つの吸収バンドは, 雲囲気 によらず，いずれの熱安定化によっても消失する。このこと から, 熱安定化過程における有機質エアロゲルの耐熱性の向 上は, 脱塩化水素化したPVC分子からの脱水素化が関与した 架橋構造の形成に起因すると考えられる。空気によって熱安 定化したエアロゲルは1717および1200 $\mathrm{cm}^{-1}$ 付近にそれぞれ カルボニルおよびエーテルの伸縮振動に帰属される吸収バン ドを示すことから, 熱安定化過程において架橋形成と同時に 酸素の取り込みも起こることがわかる。熱安定化過程におい て取り込まれた酸素は, 炭素化過程において炭素を含む分解 ガスとなって放出される。その結果, 有機物エアロゲルに対 するカーボンエアロゲルの質量比は炭素化温度が $1000^{\circ} \mathrm{Cにお}$ いて $51 \%$ 程度となる。一方, ヨウ素によって熱安定化したエ アロゲルについては, 炭素原子がほとんど放出されることな く炭素化が進行するため, 80\%の高い質量比でカーボンエア ロゲルが得られる。空気による熱安定化においては, 熱安定 化温度を徐々に $200^{\circ} \mathrm{C}$ だ上げていく必要がある。これは熱 安定化の最高温度が $200^{\circ} \mathrm{C}$ 以下では有機質エアロゲルの耐熱 性が不十分であり，また急速に温度を上げると発熱反応によ って生じた熱の蓄積によって, 有機質エアロゲルが焼失する からである。したがって, 空気による熱安定化は非常に長い 時間を必要とする。一方，ヨウ素による熱安定化においては， わずか $1 \mathrm{hr}$ の処理であっても十分な酎熱性が有機質エアロゲ ルに賦与される。したがって, ヨウ素による熱安定化はカー ボンエアロゲルの製造工程を短縮する上でも有利である。

Fig.14に有機質エアロゲル, 空気およびヨウ素による熱安定 化を用いて得られたカーボンエアロゲルのメソ孔サイズ分布 を示した。ヨウ素による熱安定化は空気による熱安定化に比 べて熱安定化および炭素化を通じての質量減少が小さいため,

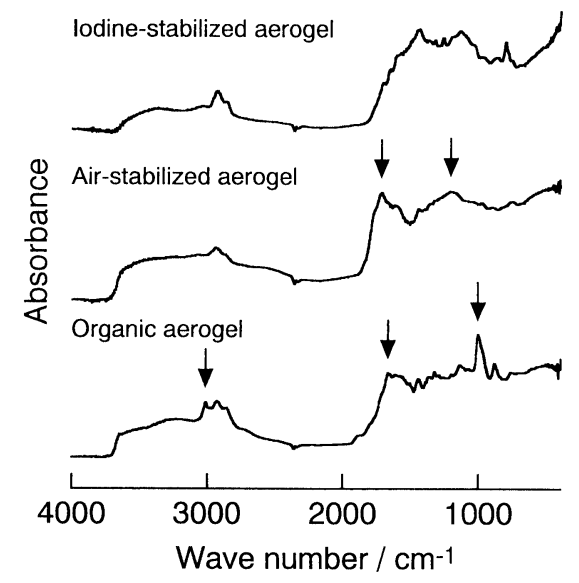

Fig.13 IR spectra for organic aerogel and air- and iodinestabilized aerogels. $\mathrm{DBU} / \mathrm{Cl}=2.0,[P V C]=5.0 \mathrm{wt} \%$ and $M_{n}=22,000$. Iodine-stabilization time was $48 \mathrm{hr}$. Arrows indicate absorption bands referred to in the text.

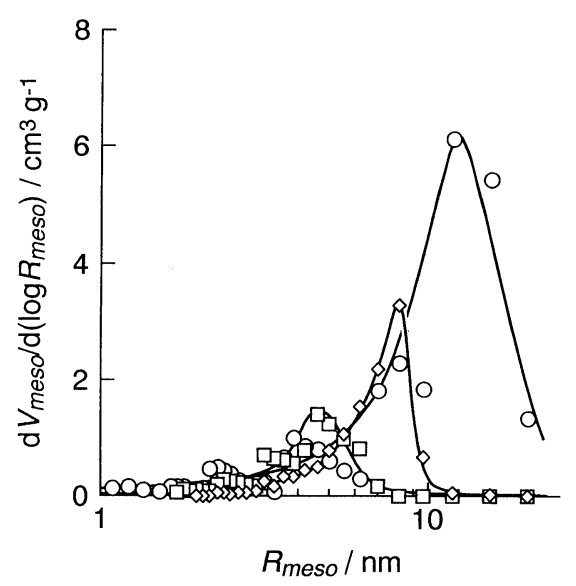

Fig.14 Distributions of mesopore radius $\left(R_{\text {meso }}\right)$ for $(\bigcirc)$ organic aerogel and carbon aerogels derived with $(\square)$ air- and $(\diamond)$ iodine-stabilization. $\mathrm{DBU} / \mathrm{Cl}=2.0$, $[P V C]=5.0 \mathrm{wt} \%$ and $M_{n}=22,000$. Iodine-stabilization time was $48 \mathrm{hr}$ and carbonization temperature was $1000^{\circ} \mathrm{C}$.

ゲルのネットワークの収縮が小さくなり, メソ孔のサイズお よび容積の減少が低減される。

カーボンエアロゲルは, 比較的サイズの大きな成形体 (モ) リス) として得られるため, メソ孔性の多孔体でありながら高 い電気伝導性を有している。このことから,カーボンエアロ ゲルは電気二重層キャパシタの電極材料への応用が活発に研 究されている54-56)。そこで, PVC系カーボンエアロゲルを二 酸化炭素ガス賦活することによって, さらに高表面積化し, 得 られた活性カーボンエアロゲルの電気二重層キャパシタ特性 を検討した。Fig.15に活性カーボンエアロゲルの有機系電解 液における電気二重層容量とBET比表面積 $\left(S_{B E T}\right)$ の関係を示 した。活性カーボンエアロゲルは同程度の比表面積を有する 


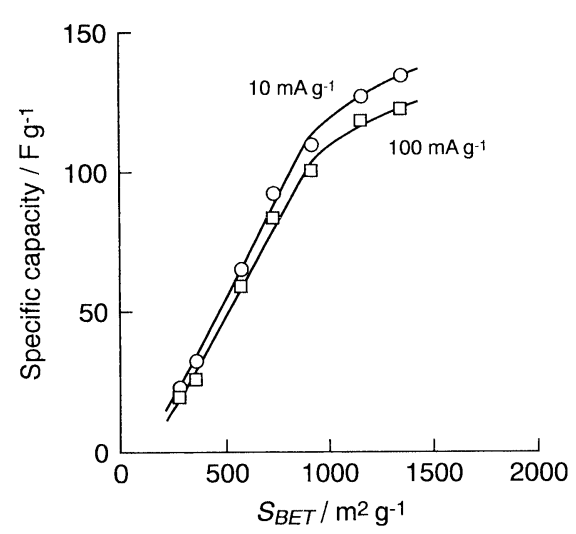

Fig.15 Electric double-layer capacity per single electrode for activated carbon aerogels versus BET specific surface area, $S_{\mathrm{BET}}$. Electrolyte was propylene carbonate solution of $1.0 \mathrm{M}$ tetraethylammonium tetrafluoroborate. Values of current density are shown in the figure.

通常の活性炭に比べて高い容量を示す57。一般に充放電電流 が大きくなると電気二重層容量は減少する傾向があるが, 活 性カーボンエアロゲルについては, その減少が比較的小さい。 これらの優れた特性は活性カーボンエアロゲル中のメソ孔の 存在に起因すると考えられる。

\section{4. ポリビニルアルコール系炭素}

ポリビニルアルコール (PVA) は水溶性である上に, ほかの ハロゲンを含むビニル系ポリマーに比べて高い比率で炭素原 子を含んでいる。したがって,ハロゲンを含むビニル系ポリマ 一の脱ハロゲン化水素化のように, PVAを脱水によって熱安 定化できれば，有機溶剤を用いない簡便な手法によって高収 率で炭素材料を得ることができる可能性がある。さらに， PVAには単結晶化が容易なことや, 粘土鉱物に特異的に吸着 するなどの特徵があり,これらを利用することによって特異 な構造や形態を有する炭素材料を創製できる可能性もある。 PVAの脱水による熱安定化に関しては, 空気中に打ける熱処 理 88 , 塩化水素と空気中に打ける熱処理を併用する方法 ${ }^{191,201}$, 酸211や硫酸水素ナトリウム ${ }^{222}$ などの各種脱水触媒を用いる方 法が試みられている。ハロゲンによる処理も効果があり, 臭 素餲和蒸気により処理する方法が特許の実施例に記述されて いる23)。最近, 著者らはヨウ素の飽和蒸気中における熱処理 がPVAの熱安定化に極めて有効であることを見出した。

PVA粉末 (け九化度 $99 \%$ 以上, 数平均分子量 50,000$)$ とPVA フィルムを実験に用いた。PVAフィルムはPVAチップ(けん 化度 $99.9 \%$ 以上, 数平均分子量 74,000$)$ を純水に溶解させて調 製したPVA水溶液を, ポリエレンテレフタレートシート上に キャストした後, 脱溶媒して作製した。フィルム厚は約 $80 \mu \mathrm{m}$ とした。PVA粉末あるいはPVAフィルムを100年におけるヨ ウ素の飽和蒸気に種々の時間暴露した。この処理によって, PVAは白色から金属光沢をもった黒色へと変化した。また，

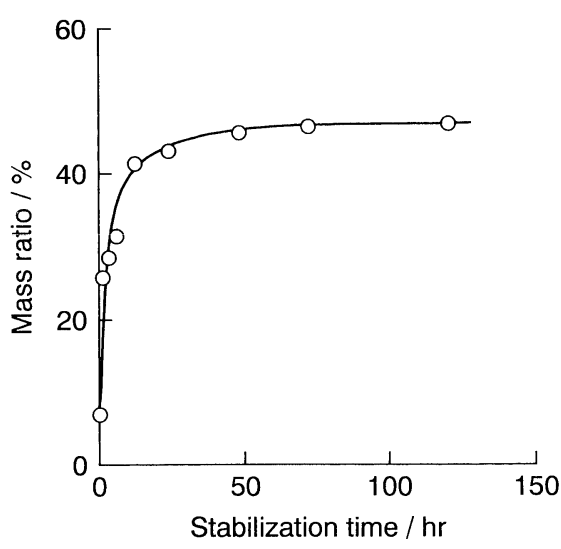

Fig.16 Ratio of mass of carbon powder against that of PVA powder versus iodine-stabilization time. Carbonization temperature was $1000^{\circ} \mathrm{C}$.

PVAフィルムについては, その剛直性が著しく増大すること が確認された。ヨウ素による熱安定化を施していないPVAを 炭素化すると, $230^{\circ} \mathrm{C}$ 付近で融解した後に熱分解してガス化 し, $1000^{\circ} \mathrm{C} に$ 扔ける炭素化収率はわずかに7\%となった。これ に対して,ヨウ素による熱安定化を6hr以上行ったPVAについ ては, 炭素化過程において形態を保持することができた。 Fig.16に示すように, $1000^{\circ} \mathrm{C}$ の炭素化における炭素化收率は 熱安定化時間の増加に伴って増大した。PVAフィルムにつ いての炭素化収率は, 熱安定化時間が120hrに扔いて $52 \% に$ 達 した。この炭素化収率はこれまで知られている中で最も高い 值である19)。ヨウ素による熱安定化におけるPVAの耐熱性の 向上は, 脱水反応による分子鎖へのC-C二重結合の導入と,そ れに続く脱水PVA分子鎖間に扔ける脱水素化が関与した架橋 形成によると考えられる。

\section{5. おわりに}

ビニル系ポリマーから化学的な手法による熱安定化と高温 熱処理を併用することによって得られる炭素材料の構造と物 性について述べた。この製造方法の最大の利点は出発高分子 の高い賦形性を利用して,さまざまな形態の炭素を製造でき る点にある。また, 通常の熱処理のみからなる製造方法では 得られない構造の炭素を得られることも有利な点である。し かしながら, 現在までのところこのような方法で炭素化が可 能な高分子は, ビニル系ポリマーのほかにはポリテトラフル オロエチレンなど少数のものに限られる ${ }^{59 .}$. 60)。今後, より多 くの高分子について化学的な熱安定化の手法を開発していく ことが, 炭素の構造や形態の制御範囲を拡げる上で重要であ ると考えられる。

\section{文 献}

1) S. E. Evysyukov, Y. P. Kudryavtsev and Y. V. Korshak, Russ. Chem. Rev. 60 (1991) 373-390. 
2) M. Kijima, Recent Res. Devel. Pure Appl. Chem. 1 (1997) 27-33.

3) L. Kavan, Chem. Rev. 97 (1997) 3061-3082.

4) E. Tsuchida, C. N. Shin, I. Shinohara and S. Kambara, J. Polym. Sci. 2 (1964) 3347-3354.

5) A. K. Mukherjee and A. Gupta, J. Macromol. Sci. Chem. A16 (1981) 783-792.

6) A. K. Mukherjee and A. Gupta, J. Macromol. Sci. Chem. A16 (1981) 1161-1181.

7) H. Kise, J. Polym. Sci. Polym. Chem. Ed. 20 (1982) 31893197.

8) T. Danno, H. Kondoh, K. Furuhata and K. Miyasaka, J. Appl. Polym. Sci. 29 (1984) 3171-3184.

9) T. Danno, H. Kondoh, K. Furuhata and K. Miyasaka, J. Appl. Polym. Sci. 30 (1985) 1219-1227.

10) B. Evans and E. A. Flood, Canad. J. Chem. 45 (1967) 1713-1714.

11) S. S. Barton, P. G. Beswick and B. H. Harrison, J. Chem. Soc. Faraday Trans. I 68 (1972) 1647-1655.

12) P. Pendletone, B. Vincent and M. L. Hair, J. Colloid Interface Sci. 80 (1981) 512-527.

13) F. F. He and H. Kise, J. Polym. Sci. Polym. Chem. Ed. 21 (1983) 1729-1740.

14) H. Kise and H. Ogata, J. Polym. Sci. Polym. Chem. Ed. 21 (1983) 3443-3451.

15) A. J. Dias and T. J. Mccarthy, J. Polym. Sci. Polym. Chem. Ed. 23 (1985) 1057-1061.

16) V. V. Korshak and Y.P. Kudryavtsev, Makromol. Chem., Rapid Commun. 9 (1988) 135-140.

17) S. Y. Yevsyukov, Y. P. Kudryavtsev, Y. V. Korshak, V. V. Khvostov, V. G. Babayev, M. B. Guseva and V. V. Korshak, Polym. Sci. U.S.S.R. 31 (1989) 29-37.

18) M. Kijima, T. Toyabe and H. Shirakawa, Chem. Lett. (1995) 553-554.

19) A. Shindo, Y. Nakanishi and I. Soma, ACS Polym. Prep. 9 (1968) 1327-1332.

20) A. Shindo and Y. Nakanishi, Nippon Kagakukai-shi (1975) 1234-1240 [in Japanese].

21) K. Maruyama, H. Akahori, M. Kobayashi and Y. Tanizaki, Bull. Chem. Soc. Jpn. 58 (1985) 2923-2928.

22）公開特許公報 昭49-24897.

23）公開特許公報 昭48-41042.

24) J. Yamashita, M. Shioya and M. Nakatani, Carbon 36 (1998) 1240-1243.

25) J. Yamashita, M. Shioya, T. Kikutani and T. Hashimoto, Carbon 39 (2001) 207-214.

26) J. Yamashita, T. Hirano and M. Shioya, Carbon 40 (2002) 1541-1548.

27) J. Yamashita, T. Ojima, M. Shioya, H. Hatori and Y. Yamada, Carbon 40 (2002) in press.

28）山下順也, 塩谷正俊, 羽鳥浩章, 山田能生, 日本学術振興会 第117委員会資料117-262-A2（2002）.

29）特許出願番号 2001-321998.

30) A. Takaku and M. Shioya, J. Mater. Sci. 25 (1990) 48734879.

31) M. G. Dobb, H. Guo, D. J. Johnson and C. R. Park, Carbon 33 (1995) 1553-1559.

32) M. Nakatani, M. Shioya and J. Yamashita, Carbon 37 (1999) 601-608.
33) K. Sato, M. Noguchi, A. Demachi, N. Oki and M. Endo, Science 264 (1994) 556-558.

34) T. Zheng, Y. Liu, E. W. Fuller, S. Tseng, U. V. Sacken and J. R. Dahn, J. Electrochem. Soc. 142 (1995) 25812590.

35) J. R. Dahn, T. Zheng, Y. Liu and J. S. Xue, Science 270 (1995) 590-593.

36) A. Mabuchi, K. Tokumitsu, H. Fujimoto and T. Kasuh, J. Electrochem. Soc. 142 (1995) 1041-1046.

37) Y. Liu, J. S. Xue, T. Zheng and J. R. Dahn, Carbon 34 (1996) 193-200.

38) K. Tokumitsu, H. Fujimoto, A. Mabuchi and T. Kasuh, Carbon 37 (1999) 1599-1605.

39) S. Brunauer, L. S. Deming, W. E. Deming and E. Teller, J. Am. Chem. Soc. 62 (1940) 1723-1732.

40) T. Zheng, Y. Liu, E. W. Fuller, S. Tseng, U. Sacken and J. R. Dahn, J. Electrochem. Soc. 142 (1995) 2581-2590.

41) H. Tamai, T. Kakii, Y. Hirota, T. Kumamoto and H. Yasuda, Chem. Mater. 8 (1996) 454-462.

42) R. W. Pekala, J. Mater. Sci. 24 (1989) 3221-3227.

43) R. W. Pekala, C. T. Alviso, F. M. Kong and S. S. Hulsey, J. Non-Cryst. Solids 145 (1992) 90-98.

44) R. W. Pekala, C. T. Alviso, X. Lu, J. Gross and J. Fricke, J. Non-Cryst. Solids 188 (1995) 34-40.

45) H. Tamon, H. Ishizaka, M. Mikami and M. Okazaki, Carbon 35 (1997) 791-796.

46) H. Tamon, H. Ishizaka, T. Araki and M. Okazaki, Carbon 36 (1998) 1257-1262.

47) W. C. Li, A. H. Lu and S. C. Guo, Carbon 39 (2001) 1989-1994.

48) D. Dollimore and G. R. Heal, J. Appl. Chem. 14 (1964) 109-114.

49) M. M. Dubinin, Chem. Rev. 60 (1960) 235-241.

50) H. Kajiura, Y. Tanabe and E. Yasuda, Carbon 35 (1997) 169-174.

51) N. Miyajima, T. Akatsu, T. Ikoma, O. Itoh, B. Rand, Y. Tanabe and E. Yasuda, Carbon 38 (2000) 1831-1838.

52) N. Miyajima, T. Akatsu, O. Itoh, R. Sakurovs, S. Shimizu, M. Sakai, Y. Tanabe and E. Yasuda, Carbon 39 (2001) 647-653.

53) N. Miyajima, S. Dohi, T. Akatsu, T. Yamamoto, E. Yasuda and Y. Tanabe, Carbon 40 (2002) 1533-1539.

54) S. T. Mayer, R. W. Pekala and J. L. Kaschmitter, J. Electrochem. Soc. 140 (1993) 446-451.

55) R. W. Pekala, J. C. Farmer, C. T. Alviso, T. D. Tran, S. T. Mayer, J. M. Miller and B. Dunn, J. Non-Cryst. Solids 225 (1998) 74-80.

56) R. Saliger, U. Fischer, C. Herta and J. Fricke, J. NonCryst. Solids 225 (1998) 81-85.

57) T. Morimoto, K. Hiratsuka, Y. Sanada and K. Kurihara, J. Power Sources 225 (1996) 239-247.

58) A. Shindo and I. Soma, Proceedings of the Symposium on Carbon, Tokyo, III-7 (1964).

59) T. T. Liang, Y. Yamada, N. Yoshizawa, S. Shiraishi and A. Oya, Chem. Mater. 13 (2001) 2933-2939.

60) S. Shiraish, H. Kurihara, H. Tsubota, A. Oya, Y. Soneda and Y. Yamada, Electrochem. Solid-State Lett. 4 (2001) A5-A8. 